\title{
EQUILIBRIUM
}

Quarterly Journal of Economics and Economic Policy

VOLUME 7 ISSUE 3, 2012

ISSN 1689-765X

Ewa Szymanik* $^{*}$

University of Economics in Cracow, Poland

\section{Business Cycles and Their International TrANSMISSION - THE INTRODUCTION To THe Problem}

\section{JEL Classification Codes: E32}

Keywords: business cycle, crisis, transmission of cycles

Abstract: The article presents the problem of business cycle transmission and the role of canals of transmission in the contemporary world. Because of the theoretical character of the problem the used methodology is a presentation of the results of the researches and theoretical works about the problem of crisis sources and their transmission.

\section{INTRODUCTION}

An issue which repeatedly appears on the pages of economic literature is the issue of cyclic changes of economic development and, strictly speaking, the issue of quite regular economic crises. As agreed by experts on the subject (e.g von Mises 2010), these issues are in the centre of researchers' attention leading frequently to levelling the terms of business cycle theory and economic depression theory.

(C) Copyright Nicolaus Copernicus University Press

Date of Submission: January 26, 2011; date of acceptance: January 4, 2012

* Contact: e-mail: szymanie@uek.krakow.pl, Uniwersytet Ekonomiczny w Krakowie, Rakowicka 27, 31-510 Kraków, Poland 
Many researchers have tried to explain the causes of emergence of crises. One of the forerunners was Kalecki, whose conjuncture model drew attention to the role of investment as a factor fuelling economy (Kalecki 1979, pp. 95-157). Other theories suggested money disproportion (Hawtrey), money overinvestment (von Hayek), innovations (Schumpeter), accidental tremors (Frisch), incomplete information during making market decisions (Lucas) (Zarnowitz 1985, pp. 548-549) or the discrepancy between a natural and market interest rate (an Austrian theory) (Bocutoglu, Ekinci 2010) as other reasons. Keynes's theory cannot be disregarded, either.

The drawback of many papers was their limited character since they often focused only on one country and factors which can cause slumps in that particular place. However, as the world economy and research on it were developing it was noticed that economic depressions very often emerge almost simultaneously in different countries. Thus, the causes and favourable conditions for such phenomena started to be investigated.

The following study focuses on the channels through which depressions or, more elaborately, cycles are transferred among economies. It is an attempt to gather findings of various researchers' studies and to indicate the most crucial, according to the author, transition channels of economic depressions. Today, in the face of the current crisis, whose results are noticeable all over the world and also in Poland, this phenomenon gained particular significance not only among scholars. This is the reason why the topic was chosen as the basis for the following study. When it comes to isolating the channels of economic fluctuations, the problem is of theoretical nature. Due to this, the methodology applied in the paper is a review of research and theoretical studies concerning the causes of the emergence of depressions and ways in which they are transmitted these days.

\section{A BRIEF HISTORY OF CYCLIC FLUCTUATIONS}

The changes in economic activity have been closely connected with the development of economies from the beginning of their existence. However, due to relatively scarce relations and weak contacts between particular countries, as well as the lack of precise sources of information, they are not taken into consideration while studying the cycles which came before the technological revolution, all the more so because they were of local character. The beginning of the research on cyclic development of economies dates back to 1819, when the first local activity slump emerged in England. It involved overinvestment in light industry and ensuing overproduction and society impoverishment. In 1825 the crisis spread over the whole English economy and related countries. It was connected with the popularization of production 
mechanization, faster and more frequent international communication as well as similar consumption model and human behaviour.

It was the worldwide slump in 1857 that afflicted different countries, even those without any close connections. It struck, among others, Italy, Russia, Great Britain, France, Germany, Spain, the USA and some of Latin American countries. The drop in prices encompassed not only industry but also agriculture, which had not been exposed to the economic fluctuations to such extent so far.

Economic development accelerated by the end of the $19^{\text {th }}$ century. Slumps were more frequent, which contributed to the changes in economies structures and application of new solutions in economic policy by the countries (Szymanik, Zyguła 2009, pp. 16-19). One of those solutions was the introduction of the gold standard. Thus, literature adopts the division of the studied period into three parts. The first one, from about 1880 till the outbreak of World War II, was characterized by minor interference into of a country into economy, which was to ensure long-term stability of prices connected with the domination of classical economy theory. In the initial stage of the second, interwar part, one could observe chaotic fiscal and monetary policy, which together with the pursuit for re-establishing convertibility of currency into gold and the policy of constant increase of its supplies in France and the USA led to the Great Depression. Finally, there is the third, post-war period, in which one can identify two subparts whose distinguishing marks were oil shocks - the one with Bretton Woods system operating, and the present one which began in the 1970's (Bergman, Bordo, Jonung 1998, pp. 67-72). An important feature of the post-war period is the synchronization of the cycle in various countries and a significant flattening of amplitude, as well as the fact that its outcomes reverberate (sometimes with delay and different intensity) throughout the whole world. The cycle also lengthened and simultaneously the course of economic processes became more irregular (Jakimowicz 2003, p. 379; Dach, Szopa 2004, pp. 201-206).

\section{SYNCHRONIZATION OF BUSINESS CYCLES FLUCTUATIONS}

As economy developed and countries tightened their mutual connections, an interest rose in the issue of synchronisation of conjuncture fluctuations among countries, especially among those highly-developed. A clash between two main hypotheses arose. The first one propagated a progressive split of the world economy into a few relatively independent centres (the present EU, the USA, Japan), whose result was said to be disintegration of the world cycle, while the second one assumed a progressive unification of economic 
systems, mechanisms and structures along with increasing interdependence, whose results involved, among others, the synchronization of conjunctures on the world scale (Hübner, Lubiński, Małecki, Matkowski 1994, p. 24).The issue became a subject of many studies, all the more so because a question appeared of when it is possible to call a cycle worldwide, that is how many and what kind of countries must be involved so that the name is appropriate. It is assumed that a cycle may be called worldwide or global if it involves countries that are economically strongest and located on different continents, so it actually means the USA, the richest countries of the EU and Japan. When describing the synchronization of cycles, Bordo confirmed a clear division into the aforementioned periods and reached the conclusion that, indeed, one could distinguish a few groups of countries in which mutual interactions are more profound and he also attested the trend of increasing synchronization, which occurs regardless of a current economic policy (Bordo, Helbling 2010). Stock in his research proclaimed the existence of an apparent increase in co-occurrence of crises in the G-7 countries and he also distinguished two groups among them, i.e. the euro zone and the Englishspeaking countries. Correlations within these groups could be easily noticed, while correlations between them where not of such significance, which could be explained by long-lasting historical bonds and their still strong influence. However, what was clearly visible was the lack of connections between Japan with its slumps and the rest of the G-7 countries. The author also paid attention to closer connections among the countries belonging to the hard core of euro zone than among the countries belonging to the so called 'old' Union, although the twelve studied union countries also displayed a distinct synchronization of fluctuations (Stock, Watson 2003).

The issue of synchronization of euro zone countries' cycles was also undertaken by numerous authors. Azevedo (2002) studied conjuncture fluctuations in the EU countries, the USA and Japan and he concluded that there was strong interdependence of fluctuations of economic activity in majority of the euro zone countries. His research shows that the conjuncture cycles in Sweden, Finland, Great Britain and the USA tend to come more than a year ahead of the euro zone conjuncture, while the cycles of the Netherlands, Italy, Japan and Spain, although still ahead, do it in less than a year. According to Bergman (2004), European cycles are highly adjusted to each other and the factor that contributes to this is the economic integration. Moreover, he argues that there are significant differences in amplitude of fluctuation in individual countries of the euro zone.

The analysis of conjuncture fluctuations and the issue of their synchronization in the EU was also covered by Skrzypczyński (2006, p. 9 and the following pages). He formulates a thesis that integration processes should lead to an increase in simultaneous existence of the same phases of cycle, espe- 
cially in the countries belonging to a monetary union. His research proved that cycles in the euro zone and in the "core" countries of the EU, meaning the first and the economically strongest member countries, are strongly related with each other. He also determined that a typical cycle in the euro zone lasts from 3 to 5 years and he drew a conclusion that taking common currency is beneficial for the stabilization of adjustment of conjuncture fluctuations.

The question of the existence of a European conjuncture cycle was also posed by Artis (2003, p. 4 and the following pages). While analyzing data concerning GNP of 22 countries from the 1970's to the early years of the new millennium, including the countries that belonged to the EU then, he noticed a tendency for generating a higher number of cycles than in the USA as well as closer connections among these countries than among other European countries and that is why it would be more appropriate to call such a cycle a "union" cycle. He also noticed that Finland was in a distinct phase of the cycle while Portugal, Ireland, Great Britain, Sweden and Denmark did not display close connections with those countries that formed "the core" of European structures. The connection between the latter and Japan and Norway became clearly noticeable. Relying on his research, the author concluded that connections of the cycles between countries are more influenced by globalization processes than by building a unitary economy of the EU. He explains: 'In the same way as a conjuncture cycle may be shown as a result of an expansion mechanism of similar transfer mechanisms, asymmetric shocks may cause common shocks with different transfer mechanisms as well as asymmetric shocks accompanied by mechanisms similar to each other.' It induced him to propose broader research aiming at isolating typical elements characterising the mechanism.

The existence of an international conjuncture cycle was also acknowledged by Backus and others (Backus, Kehoe, Kydland 1993), who focused on the differences between theoretical assumptions of the occurrence of fluctuations and economic reality. The main disproportions concerned quantity and price anomalies, however, the authors point out that some mistakes are possible here due to too limited number of factors considered. Apart from acknowledging the existence of such cycles, Ahmed and others (Ahmed, Ickes, Wang, Yoo 1993, pp. 336-358) notice that generation of cycles is influenced by supply shocks, especially those that are characteristic for a particular country, and that despite some changes in the world economy after the first oil shock, there are no significant differences in the mechanisms of their transfer.

Kose and others (Kose, Otrok 2008) reached a similar conclusion. Apart from recognizing the existence of the world cycle, they notice the influence of globalization factor on the transfer of fluctuations, which is, however, 
more important for countries with highly developed industry. They also confirm the existence of shocks that are specific for some groups of countries, an example being the EU, which are related to the factors specific for a particular group; transition of shocks within one particular group of countries produces stronger results than transition within the world cycle. Their third claim concerns an important role of still not thoroughly examined conditions of risk transition on an international scale, which is also more evident among different groups of countries than on a global scale.

Arkolakis and Ramanarayanan (2009) scrutinized the relations between vertical specialization in foreign trade and convergence of cycles in different countries, which confirmed other authors' findings (e.g. Frankel and Rose 1998, pp. 1009-1025) that countries maintaining more extensive trade exchange also display higher degree of synchronization of their cycles, though the connection is not a strong one and it is not dependent on changes in trade intensity. The same issue was also pondered on by Baldwin and Krugman (1989, pp. 821-854), who suggested that companies' decisions about export have a strong influence on transition and coordination of cycles in different countries. Alessandria and Choi (2004) noticed that features of international conjuncture cycle depend on how the demand for foreign goods changes in a specific country. If this changeability is low, that is when consumers show a high stability of basket of imported goods they purchase, countries with strong trade connections present quite visible convergence of cycles. The conclusion that follows is that export, which changes slower than any other elements of global demand especially investments in fixed capital, plays an important role in mitigating cyclic fluctuations.

Raban and others (Rabanal, Rubio-Ramírez, Tuesta 2009) point at the role of technological investment shocks in the course of a cycle and their influence on other countries. In a country afflicted by such a shock investments grow and consumption decreases. If goods are produced with the use of imported components, their price goes up contributing to the drop in exchange rates of national currency. It equals to the enrichment of foreign consumers due to an improvement of terms of trade, which will, according to the authors, result in an increase in consumption abroad. This approach presents a negative relation between particular economies, pointing rather at desynchronization of a cycle; however, at the same time it explains high changeability of the US dollar exchange rates within the last 20 years. Unfortunately, the authors did not show how and in what way changes in the American dollar exchange rates affected the transmission of conjuncture cycles and their synchronization in other countries.

Having this short literature overview in mind, one may conclude that proceeding integration of the world economy as a whole limits the negative influence of dominating world economies on the rest by reducing the ampli- 
tude of cyclic fluctuations. Another explanation may be structural changes in particular economies connected with an expanding role of service industry and public sector, which are less prone to conjuncture slumps. Bergman (Bergman, Bordo, Jonung 1998, pp. 78-79) also reasons that a conjuncture cycle is not symmetric and that although recessions originating from the USA are the most extensive ones, not all of the world economies are affected by them in the same manner and time, which can be supported by the course of the last crisis.

\section{SPREADING OF CRISES}

Questions about the main forces of emergence and transition of crises are raised in many publications. Some of those forces have already been identified, for example shocks connected with production factors, fiscal and monetary policy, oil prices, rapid changes of terms of trade, consumers' preferences or important information. Moreover, these forces are influenced by a range of national and foreign factors, so a necessity appears to understand their importance in order to examine better the channels of transition of conjuncture cycles (Crucini, Kose, Otrok 2008, p. 2). It is necessary to add that the factors are often related to each other so it is hard to isolate them in their pure form without referring to their mutual connections and correlations.

As it has already been mentioned, modern economic slumps are of international character, that is, they influence the majority of countries either in a stronger or weaker manner. A crisis does not have to develop fully in a particular country in order for its consequences to be felt abroad. It must be remembered that sometimes the sources of a slump are external and a given phenomenon in its home country does not have to bring any negative results, which does not mean that one can separate the process of recession development in a particular country from its international transmission (Mazurek, 2009, p. 24).

International transmission of crises can be defined as the spreading of crisis phenomena on a world scale, which is often called a 'contagion effect'. At the beginning, the term was used only in relation to the spread of currency crises or, more generally, of financial perturbations. The World Bank suggests three definitions of a contagion ${ }^{1}$ :

- a contagion is an international transmission of shocks or, in other words, an international interaction (a spillover effect);

${ }^{1} \mathrm{http}: / / \mathrm{wwwl}$.worldbank.org/economicpolicy/managing\%20volatility/contagion/definitio ns.html, accessed on 15.12.2010 
- a contagion is a transmission of shocks to some other countries or a connection between economies that goes further beyond some fundamental relations and shocks originating from the same sources (common shocks);

- a contagion occurs when a correlation between economies is stronger during the period of a crisis than during stillness.

The first definition does not assume that transmission is related only to crisis phenomena; however, it is more clearly visible in periods of an economic slump. The second definition describes very similar changes in markets, while the third one is very narrow and covers only negative changes, which seems quite obvious as such events influence society to a larger extent.

Rigobon (2001) advances a slightly different definition of a contagion. According to him one may talk about a contagion only when:

- it relates to markets, whose mutual economic connections (e.g. via trade) are fairly weak,

- stimuli spread much faster and more violently than they would do as a result of regular economic ties and similar economic bases,

- the range and scale of fluctuations are wider than it would be expected on the basis of a classical transmission effect.

It is the most common view in literature that a crisis in one country somehow leads to a similar situation in another one, with the assumption that these two economies are independent but still connected within bounds of the world economy. Recession spreads in a geographical dimension so it may be called a horizontal one.

What must be remembered is the aforementioned fact that not every crisis in a particular country must be related to the whole economy. Some slumps affect only some sectors and as particular areas are linked, a slump in one domain will affect the others. The recession which spreads in this way can be related to as a vertical one. More precisely, a vertical transmission is a way leading from a collapse in one domain to a recession of the whole system of economy or a passage from one stadium of a crisis to another one in a different domain. Mazurek (2009, pp. 25-26) defines the mechanism of transmission of crises as one that consists in undergoing various types of slumps or, in other words, in spreading of recession to successive economic (e.g. economic branches or sectors) or geographical (country, region or national economy) domains.

A specific asymmetry of a contagion is also significant; a reaction to bad news is much stronger than to good news. Moreover, a contagion is more frequent in less developed countries than in economically advanced ones (Barczyk, Kąsek, Lubiński, Marczewski 2006, p. 106), which may be a result of developing peculiar 'immunity to contagion' that is effective methods 
of economic policy, which are to prevent transmission of crises or, which is more likely, to mitigate their outcomes.

Theories of contagion are in the centre of economists' attention nowadays. They are divided into two groups. The first one takes into account peculiarities of critical periods (crisis contingent), while the second one lacks in this element (non-crisis contingent). Within the first group one is able to find theories claiming that a slump in one country increases the probability of its occurrence in other countries, whereas the second group includes those that involve factors like international trade, coordination of countries' economic policies, evaluation of credibility and of a country's rating or asymmetric shocks in transmission of impulses. The first group is based on Krugman's while the second one on Obstfeid's ideas (Barczyk, Kąsek, Lubiński, Marczewski 2006, p. 107).

As it has already been mentioned, theories of contagion which search for the reasons of expansion of crises refer to various phenomena with an emphasis on foreign trade and exchange rates. When studying currency crises, Obstfeld (1994) paid attention to the fact that even a minute, seemingly insignificant incident may throw economy out of balance (which is characterized for example by stable exchange rates) and push it into one that is acquired in the period of a crisis. Such possible reasons are explained, among others, by the concept of information cascade. Its essence is a claim that in the state of information asymmetry transactors take decisions not only on the basis of their own knowledge but also take into account other transactors' behaviour (Barczyk, Kąsek, Lubiński, Marczewski 2006, p. 108). That brings an explanation to herd instincts in economy, when a particular transactor makes decisions similar to those which he observed among other transactors, even though they may be wrong.

It has already been pointed out that crises are transmitted both vertically and horizontally, hence in the conditions of open economy and financial markets connected with each other, it is crucial to take into account one important aspect of the role of information in a contagion process. According to the authors of this theory, even if investors predict a slump, they reach the conclusion that a premature reaction may not be profitable for them and thus they try not to act too hastily. Only other investors' actions make them adapt to the situation, so an outbreak of a crisis on one market confirms their individual suspicions concerning a slump in other countries (Caplin, Leahy1994).

What should also be stressed is the fact that a sudden slump must occur for the crisis to spread uncontrollably. If it is expected, investors have enough time to prepare themselves by taking proper precautions and gradual withdrawal from an infected market without panic. The basis for predictability of a crisis are two indicators - an evaluation of credit credibility conduct- 
ed by rating agencies and a span of interest rates on a domestic and foreign capital market (Barczyk, Kąsek, Lubiński, Marczewski 2006, p. 120).

\section{TRANSMISSION CHANNELS OF CRISES}

A transmission channel is a name for an international connection between two or more national economies, through which a reciprocal transfer of conjuncture impulses, especially of economic crises, may occur. Among the most important channels one may enumerate:

- international finances,

- international trade,

- psychology of market players' behaviour,

- international policy or home policy with international implications (Mazurek 2009, p. 27).

Financial markets constitute an important transmission channel. The channel is related to the development of complex financial institutions in different countries of the world. One of its basic instruments is stock exchange, and more precisely the situation in the most significant countries of the world. As an example, a crisis in the USA will affect markets in other countries while a crisis on stock exchange in Warsaw will not cause such significant repercussions. Obviously, it does not mean that a crisis in the USA will influence other foreign markets to the same extent. The problem is really complex, which is supported by the example of the current crisis and the comparison of its course for example in Poland, Western European countries and the USA.

The research on the relation between transactions on the world bank market and a conjuncture cycle was also carried out by Kollman and others (Kollmann, Enders, Müller 2010). Their research shows that capital requirements of banks have a weak influence on the international transmission of production shocks. The second conclusion relates to an almost complete lack of connections between shocks caused by the cessation of distribution of bank loans and conjuncture cycles in usual conditions. However, according to the third observation, an exceptionally strong slump on loan market in one country may induce a significant and simultaneous slowdown of economic activity in the countries connected with the initial one. It is noteworthy that the last financial crisis, which started in 2007, was characterized by great losses on American credit market and a simultaneous sheer drop competitive devaluation in production both in the USA and the euro zone. The findings suggest that global banking may play a significant role in the world spread of crises due to its vast connections and fast pace of transmissions; it is also most likely that the state of banking sector did not play any important 
role (read further in Rosati 2010, pp. 123-124; Flejterski 2010, pp. 136140).

Another transmission channel, being also one of the oldest, is foreign, or more extensively, international trade. Theories which underline its role relate to the concept of; when occurring in one country, the devaluation (caused for example by a currency crisis) improves the country's competitiveness in relation to its partners, which may expose them to a trade gap and the loss of foreign exchange reserve and their currency to a speculative attack (Gerlach, Smets 1995). It is called a competitiveness effect.

The mechanism is enhanced by the fact that devaluation, which stems from a currency crisis, is very often accompanied by a production slump which causes a decrease in import, which further intensifies partners' economic difficulties. Thus, an income effect appears.

Another result of devaluation is a supply effect of cheap import, which positively stimulates economy since currency devaluation decreases the costs of import for trade partners. However, it is a short-term action as it makes partners also execute devaluation. This phenomenon is known as a free-will contagion (Barczyk, Kąsek, Lubiński, Marczewski 2006, p. 115).

The relation between the deterioration of terms of trade and devaluation is also an important point for consideration. In case of any external disturbances generated by conjuncture fluctuations, currency crises may become a transmission channel for conjuncture impulses, which can appear in different forms. One of them is a decrease in export, whose consequences may involve a decrease in production, growing unemployment or growing deficit on current account. In such a situation devaluation will be the price a government will need to pay for an economic boost (Barczyk, Kąsek, Lubiński, Marczewski 2006, pp. 59-61).

Workforce migration, observed especially in the $19^{\text {th }}$ century, belongs to the group of older transmission channels. Immigration makes up for the missing workforce in periods of boom, introducing new elements into the course of economy. It also makes the phase of growth lengthen due to an increased consumption demand (Hübner, Lubiński, Małecki, Matkowski 1994, p. 182). On the other hand, it may also improve the situation in the emigrants' country by reducing unemployment, impeding a decrease in payments and contributing to the expansion of export (emigrants often search for their native products, especially food). In this way fluctuations may be mitigated. However, migration is very often accompanied by a brain drain irrespective of an emigrant's level of education. People who decide to take such a step are usually entrepreneurial and unafraid of taking new challenges, and even though in the beginning they occupy segments on the market which are not popular with local people they soon get used to the new 
situation and pick up the language and gradually move to some other, betterpaid and more prestigious professions.

The situation gets more complicated during a crisis. If the emigration is clearly connected with earnings, after losing their jobs emigrants often decide to go back to their homeland where they join the ranks of the unemployed. However, it does not have to improve the situation in the country they come back from since the positions they have left are usually of poor quality and as such they are not immediately taken by the locals. On the other hand, the already known effect occurs - acquired new consumption habits may lead to the growth of trade exchange and become a source of anticrisis impulses.

Emigrants' income is also worth mentioning. It influences the level of production, structure of prices, income of the public and private sector as well as the balance of payments in the country of emigration. The results of fluctuations of transfers depend on their contribution to national income and the balance of payments. However, usually their value is too low to cause any greater economic growth, the more so because they are intended for consumption not investment (Hübner, Lubiński, Małecki, Matkowski 1994, p. 184).

All these considerations lead to the conclusion that nowadays the role of migration as a channel of transmission of conjuncture fluctuations consists in the transmission of human assets and related knowledge, which may contribute to long-term mitigation of fluctuations on the world scale

The next transmission channels of crises is information, its incompleteness and at the same time facility and quickness with which it can be obtained. What follows is the fact that the channel itself does not have to be strictly of economical character; what is only important is that the connection produces economic effects in related economies (Mazurek 2009, p. 28).

One of the newer factors influencing the correlation of economies is a phenomenon which may be called an import of moods. The factor develops as a result of progressing globalization and universalization of mass media and it is connected with the previous factor, i.e. information. According to this mechanism, the behaviour of investors on numerous markets, especially the developing ones (also in Poland), depends on economic trends and foreign investors' moods even if they do not have any direct connections with a particular economy and its bases of development. Import of moods is threatening as it distorts the carrier of information, namely mass media. Naturally, it is all about susceptibility of human psyche to herd instincts, which has been explained before. A remedy for such a distortion would be supervising investors and obliging them to gain specialist knowledge which would allow them to analyze economic phenomena and to predict their consequences for a particular country (Marczak, Piech 2009, pp. 8-9). However, 
this view is hard to agree with since even the best prepared analyst is only a human and he or she may be wrong, which is supported by the example of experts whose prognoses concerning changes in economy are sometimes completely different from what really happens later.

Sure enough, the role of transmission of moods across borders is growing together with the development of globalization while the role of factors connected with capital flow lessens. A new phenomenon appeared, that is 'trust management', which is strongly connected with the before mentioned flow of information and the role of central banks. These banks started to disclose information on how they make decisions and they multiplied publications of reports on economy. However, even improving availability of information does not guarantee proper evaluation of phenomena and protection from crises. It is related to an important psychological factor being fear (Marczak, Piech 2009, p. 10). Terms such as 'contagion' (fear may be contagious) or 'panic' (for example economic one) and ensuing damages do not appear in literature on economy in vain. Very often fear is their source, which suggests that studies on economy should be broadened and cover also some immeasurable phenomena connected with psychological factors.

There is one more transmission channel of conjuncture cycles related to the previous ones, mainly foreign policy or home policy with international outcomes. An example comes from Greece, where the reforms in public finance sector were desisted, which resulted in the necessity for an intervention of the rest of euro zone countries in order to save the common currency and prevent the consequences of threat of bankruptcy spreading from Greece to other countries due to its connection with the common currency. It is also a good occasion to ask further questions if there is any sense in allowing unprepared countries for adopting the euro. It is not, however, the subject of research in this study.

Another example may be military interventions made by the USA, which charged the American budget; partial funding of the expenses on arms by printing money, resulted in an increase in inflation and a decrease in the dollar exchange rates, causing also other substantial repercussions to the world economy.

An important question arises, namely, why crisis phenomena not always spread from one country to the others. Kaminsky and others (Kaminsky, Reinhart, Vegh 2003) deliver the answer. According to them, what is more important than similarity of goods and geographic structure of foreign trade, are connections with the regional finance centre. Three basic cases are possible here:

- a shock occurs in one of the peripheral countries and it spreads directly to other related countries, 
- disturbances spread among the peripheral countries via a regional economic or financial centre,

- a shock appears in the centre and it is transferred to the related countries. One should also pay attention to the condition of economies, which influences susceptibility to contagion. Despite being connected by the same transmission channels, countries have different levels of susceptibility. It is a derivative of numerous factors, of which the size of a particular national economy, understood as possibility to influence the world economic parameters, is the most important. The strength of this influence, shaped by the share of given economy in a particular branch or sector, is of vital importance. The connection causes asymmetry of transmission channels, which means that countries susceptible to contagion have relatively weak opportunities of infecting others. To show it more vividly: when a large economy has a cold others will also catch it while the flu of a small economy will not be usually noticed even by the closest neighbours. However, it does not mean that bigger economies are immune to contracting a crisis. Immunity of an economy is more an outcome of its lower susceptibility to problems in different spheres (for example because of greater flexibility of an economic structure or diversification of internationalized trades and sectors) rather than of limitations within the framework of specific transmission channels (Mazurek 2009, p. 30). Thus, the most important problem of today's economies is how intensive an impact of a crisis will be for a country and how resistant the country will be to the outcomes of the crisis. The significance of this factor is well represented by the example of Poland and its apparent 'immunity' (further on the relations between the growth of GNP and national debt in Poland and the anticipated consequences in Jankowiak (2010).

While discussing transmission channels of economic phenomena one should not forget to mention the existence and significance of time lags, which affect the course and consequences of a crisis in a particular country. The quickest transfer of impulses exists in the sphere of information and on financial markets, while the slowest one is in the real sphere. Sometimes because of that, an overlap of the effects of previous slumps and new sources of fluctuations appears and due to that it is hard to separate them. It causes high changeability of transmission paths and as a result the way economies interact with each other changes over time. That is one of the reasons why it is hard to transfer directly the means of mitigating the consequences of slumps from previous periods to the next and from some countries to some others.

Another important matter is the existence of feedbacks. The coexistence of time lags and the efforts to mitigate negative forces of reactions in the economies affects not only a country which was 'given' the recession but also the countries from where it is transmitted (since such an attack is a re- 
sult of contacts not only with one country). What may result from such a course of action is for example the prolonged recession in an infecting country caused by problems of the infected economy (Mazurek 2009, p. 31). Developing globalization intensifies economic ties among countries and increases correlation of conjuncture cycles, which has been approved by numerous authors such as Artis, Okubo (2008). At the same time, the pace of transfer of fluctuations changes over time, which depends on the extent of integration of the economies and the economic power of an infecting country (Y1lmaz 2009, pp. 15-16).

\section{CONCLUSIONS}

A conclusion drawn from the foregoing discussion on the channels through which fluctuations spread is that they are related to each other and due to the present-day conditions in economy one cannot talk about only one transmission channel since the contagion effect is a multidimensional phenomenon. The connections among them are more or less close and it depends more on a sum of factors defining a situation of a particular country rather than on a specific cause of crisis. Very often it is also hard to see the difference between the source of slumps and a transmission channel they spread through. Certainly, the main factor favourable to the spread of crises is quick flow of information; mutual connections of global banking constitute the second one.

They both contribute to accelerating the pace at which especially negative phenomenon spread on the global scale. But they also, due to the familiarity with means applied in particular countries, can help to stabilize economy and because of synergy phenomenon they can mitigate outcomes of slumps in particular countries. It is also beyond doubt that there are three main sources - countries where crises are born: the USA, the EU with the leading role of the euro zone and Japan; their connections with other countries and their stage of development make crises spread fast, although it does not mean that to the same extent and to all countries, which is supported by the example of the current economic situation.

It should be also stressed that many large and populous Asian countries (China and India in the first place) joined the world economy in the recent years. If the pace of their economic growth keeps exceeding the dynamics of growth in the USA and Europe it is very likely that it will be Asia which will become the economic centre of the world and play an important part in shaping conjuncture in the world.

One more conclusion emerges from the study of transmission channels of crises presented in this thesis, namely that along with the economic devel- 
opment, new paths of transfer of conjuncture fluctuations appear; thus, it is probable that hitherto studies did not cover the subject fully. What is more, some new transmission mechanisms are likely to appear in the future and their detection may be enhanced by a broader view on economy which takes other fields of science into account.

\section{LITERATURE}

Ahmed S., Ickes B., Wang P., Yoo B.S. (1993), International Business Cycles, "The American Review", June.

Alessandria G., Choi H. (2004), Export Decisions and International Business Cycles, Society for Economic Dynamics, NY University, Meeting Papers 54, New York.

Arkolakis C., Ramanarayanan A. (2009), Vertical Specialization and International Business Cycle Synchronization, Federal Reserve Bank of Dallas, Globalization and Monetary Policy Institute, "Working Paper" No. 21, September .

Artis M. (2003), Is there a European Business Cycle?, CESifo "Working Paper" No.1053, Category 5: Fiscal Policy, Macroeconomics and Growth, October.

Artis M., Okubo T. (2008), Globalization and Business Cycle Transmission, CEPR "Discussion Paper" 7041, Kobe, October.

Azevedo J. (2002), Business Cycles: Cyclical Comovement Within the European Union in the Period 1960-1999. A frequency domain approach, "Working Paper" WP 5-02, Banco de Portugal.

Backus D. K., Kehoe P.J., Kydland F. E. (1993), International Business Cycles: Theory vs. Evidence, "The Federal Reserve Bank of Minneapolis Quarterly Review", 1742, Fall 1.

Baldwin R. E, Krugman P. (1989), Persistent Trade Effect of Large Exchange Rate Changes, "Quarterly Journal of Economics", 104(4).

Barczyk R., Kąsek L., Lubiński M, Marczewski K. (2006), Nowe oblicza cyklu koniunkturalnego, PWE, Warsaw.

Bergman M. (2004), How Similar Are European Business Cycles?, "Working Paper" No. 9, Lund University, Department of Economics.

Bergman U.M., Bordo M.D., Jonung L. (1998), Historical Evidence on Business Cycles: The International Experience, [in:] Beyond Shocks: What Causes Business Cycles, Federal Reserve Bank of Boston, Conference Series 42, ed. J.C. Fuhrer and S. Schuh, June.

Bocutoglu E., Ekinci A., Austrian Business Cycle Theory and Global Crisis, "Mises Daily" 5.02.2010, dostępne na http://mises.org/daily/4072 (stan na dzień 14.12.2010).

Bordo M. D., Helbling T.F. (2010), International Business Cycle Synchronization in Historical Perspective, NBER Working Paper Series, "Working Paper" 16103, NBER, Cambridge, June.

Caplin A., Leahy J. (1994), Business as Usual, Market Crashes and Wisdom after the Facts, "American Economic Review", No. 3. 
Crucini M.J., Kose M.A., Otrok Ch. (2008), What Are the Driving Forces of International Business Cycles?, NBER "Working Paper" No. W 14380, October.

Dach Z., Szopa B. (ed.) (2004), Podstawy makroekonomii, PTE, Kraków.

Flejterski S. (2010), Globalny kryzys bankowo - finansowy. Geneza, aktorzy, konsekwencje, w: Kołodko G. (red), Globalizacja, kryzys i co dalej?, Poltext, Warszawa.

Frankel J.A., Rose A.K. (1998), The endogeneity of the optimum currency area criteria, "The Economic Journal" 108 (449).

Gerlach S., Smets F. (1995), Contagions Speculative Attacks, "European Journal of Political Economy", No. 1.

http://wwwl.worldbank.org/economicpolicy/managing\%20volatility/contagion/defin itions.html, (accessed on 15,12.2010).

Hübner D., Lubiński M., Małecki W., Matkowski Z. (1994), Koniunktura gospodar$c z a$, PWE, Warszawa.

Jakimowicz A. (2003), Od Keynesa do teorii chaosu, PWN, Warszawa.

Jankowiak J. (2010), Dług publiczny: garb albo lewar?, "Pioneer”, nr 2.

Kalecki M. (1979), Próba teorii koniunktury, [in:] Kalecki M., Dzieła, Kapitalizm. Koniunktura i zatrudnienie, PWE, Warszawa.

Kaminsky G. L., Reinhart C. M., Vegh C. A. (2003), The Unholy Trinity of Financial Contagion, NBER "Working Paper" No. 10061, Cambridge, November

Kollmann R., Enders Z., Müller G. J. (2010), Global Banking and International Business Cycles, ECORE Discussion Paper, 79.

Kose M.A., Otrok Ch. (2008), Global Business Cycles: Convergence or Decoupling?, IZA Discission Paper Series, "Discussion Paper" No. 3442, April.

Mazurek Sz. (2009), Ścieżki międzynarodowej transmisji kryzysów, [in:] CzechRogosz J., Pietrucha J., Żelazny R. (ed.), Koniunktura gospodarcza od bańki internetowej do kryzysu subprime, Wydawnictwo BECK, Warszawa.

Mises L.H.E., The Austrian Theory of the Trade Cycle, http://www.mises.org, (15.12.2010).

Obstfeld M. (1994), The Logic of Currency Crises, NBER "Working Paper" No. 4640, Cambridge, September.

Rabanal P., Rubio-Ramírez J.F., Tuesta V. (2009), Cointegrated TFP Processes and International Business Cycles, IMF "Working Paper" WP/09/212, September.

Rosati D.(2010), Przyczyny $i$ mechanizm kryzysu finansowego $w$ USA $w$ latach 2007-2009, [in:] Kołodko G. (red), Globalizacja, kryzys i co dalej?, Poltext, Warszawa.

Skrzypczyński P. (2006), Analiza synchronizacji cykli koniunkturalnych $w$ strefie euro, NBP, „Materiały i Studia”, zeszyt nr 210, Warszawa, September.

Stock J.H., Watson M.W. (2003), Understanding Changes in International Business Cycle Dynamics, NBER “Working Paper” 9859, NBER, Cambridge, July.

Szymanik E., Zyguła A.(2009), Cykliczne wahania aktywności gospodarczej, Krakowskie Towarzystwo Edukacyjne sp. z o.o., Oficyna Wydawnicza AFM, Kraków. 
Yılmaz K. (2009), International business cycle spillovers, Tüsiad-Koç University Economic Research Forum, "Working Paper" 0903, September.

Zarnowitz V. (1985), Recent Work on Business Cycles in Historical Perspective: A Review of Theories and Evidence, "The Journal of Economic Literature", Vol. 23. 